\title{
Ideology, Power and Translation in Palestine
}

\author{
Nadia Ali Khaleel Salous* \\ Palestine Technical University - Kadoorie
}

DOI: $10.36348 /$ SJHSS.2019.v04i10.003

| Received: 10.10.2019| Accepted: 18.10.2019| Published: 30.10.2019

*Corresponding author: Nadia Ali Khaleel Salous

Abstract

In this study I hope, without claiming comprehension, to shed lights over the process of translation in Palestine, by giving modals from different stages with different source languages (Arabic, English, and French). The process of translation was highly respected by almost all Palestinian intellectuals and three figures will be mentioned in this study: Adel, Zuaiter, Khairi Hammad and Salma Jauuysi, each Palestinian icon will be treated through the study individually, identifying his or her particular ideology, influencing factors and the resulting effects on his production; general conclusions follow, and close the study. The study discusses the movement of translation since the twentieth century till now and the two main characteristics of translation in Palestine, in the twentieth century, are easily recognized, both of which are closely linked to political struggle in Palestine and the Middle East. The study covers the effects of ideology, and power over the translator's production and the specific definition that those terminologies having in this study and the impacts they had at the time. The study will be closed by a number of recommendations and conclusions.

Keywords: Ideology denotes "the ideas and views that represent a certain interest group", Power denotes "the Arab states, which were dominant with their army, police and information services".

Copyright @ 2019: This is an open-access article distributed under the terms of the Creative Commons Attribution license which permits unrestricted use, distribution, and reproduction in any medium for non-commercial use (NonCommercial, or CC-BY-NC) provided the original author and source are credited.

\section{INTRODUCTION}

Despite the importance, diversity and large quantities of the material of "translation in Palestine", and despite the great role played by ideology and power in its production and dissemination; yet, few studies were done on the subject "Ideology, Power and Translation in Palestine" in particular, or even on the more general subject "Translation in Palestine"; for example, Hussam al-Khatib's book Haraket al-Tarjama fi Falastin and Fatima Hamad's book Mutarjimat min Falastin. This study hopes, without claiming comprehensiveness, to contribute to this important project, by discussing the subject through a sample drawn from the main related languages: Arabic, English and French; and the most famous Palestinian translators.

In this study, ideology denotes "the ideas and views that represent a certain interest group [2]". For the purposes of the study, ideology is divided into three categories: Arab and Palestinian nationalist, common to all three translators, liberal that is characteristic of Zuaiter, and leftist or socialist who applies to Hammad.

As for power, it denotes here, the Arab states, which were dominant with their army, police and information services and media at the time, representing, though with varying degrees, the interest of external or internal powers, but could be argued to constitute interest groups in themselves.

The translation movement in Palestine like the Arab countries in the twentieth century took the form of a mutation rather than a gradual evolution. Widespread illiteracy, poor cultural advance of the Ottoman state, and the adverse traditions that considered translation an illicit act, all were combined in opposing the advance of the translation movement. Only after collapse of the Ottoman Emperor and direct contact with the west did translation begin its long march forward.

Two main characteristics of translation in Palestine, in the twentieth century, are easily recognized, both of which are closely linked to political struggle in Palestine and the Middle East:

- Change of the source language with succession of time: Turkish, Russian, English and French, then Hebrew and Arabic.

- Change of the message carried by the process of translation: First, when Arabic was the target language, it was the exploration of the factors of renaissance that dominated the 
source, but after 1948, the year of the Catastrophe Nakbeh, the message focused on addressing the western world in defending the Palestinian cause and informing the west of the real nature of Palestinian and Arab reality and civilization.

The three characters chosen by the study to represent the translation movement in Palestine enjoy many merits: They are held with high esteem by Palestinian writers and intellectuals; their works cover diverse domains: Sociology and law (Zuaiter), contemporary history (Hammad), and Palestinian and Arabic literature (Jayyusi). Having diverse ideological orientations: Nationalists, leftists and liberals. In addition, they can be said to have represented a wider span of time i.e. from 1920 to the present, also dealing with different source languages.

Beginning with the earliest translator i.e. Adel Zuaiter, the study will treat our translators individually, identifying for each his or her particular ideology, influencing factors and their resulting effects on his production. General conclusions follow and close the study.

\section{Adel Zuāiter}

Adel Zuāiter was born in 1897 in Nablus, received his elementary and secondary education in Nablus and Beirut, then he joined the Sultan's College in Istanbul where he mastered, in addition to Turkish, French which became the main source language of his future translated works. In 1925, he graduated from France, with a certificate in law, deeply influenced by the ideas and viewpoints of his teacher, Gustave Le Bon.

Between 1927 and 1936, Adel Zuāiter worked as a teacher in the Institute of Law in Jerusalem, practicing meanwhile various political activities against the Imperial project of the British Mandate, but the results were poor and baffling. Therefore, he decided to shift his activity from the local level to the Arab level, consecrating all his time and effort to translation, which continued till his death in 1957.

The resulting output was colossal indeed: about 38 translated books, generally large volumes, which included the masterpieces of the French (and German) celebrated thinkers, like Roussean, Voltaire, Montesquieu, and Le Bon who had the lion's share in these translated works.

In the case of Zuāiter, ideology may be considered the main factor affecting his choice in translations. His ideology consisted of two powerful components: (1) nationalism which has Arabic-Islamic culture at its core, and (2) liberalism with its essential values of freedom, individualism and particularly elitism which ascribes historical changes to the elite and technology.

Here is what he says in his introduction to Le Bon's 'Les Lois Psychologique de L' Evolution ds Peuples":

"The principle of equality among individuals and races preached by philosophers in the eighteenth century became a firm belief of the majority of the peoples of Europe in particular. This principle was so influential in these people as to turn the western world upside down; this principle is the base underlying socialist theories. Despite the weakness indicated by modern science of this principle, nobody dared challenge it with exception of a few scientists headed by Le Bon who showed in his book that the more the civilizations developed the more individuals and peoples become inequal, and that humanity is heading towards inequality and not equality. One of the findings of Le bon is the fact that races differ in the elites they contain, and that civilization gradually leads to mental discrepancy among individuals, and the more the nations progress in civilization the more the inequality between the two sexes takes place."

From this text and other texts, it is clear that Zuāiter stood with Le Bon without reservation, contrary to some other Arab thinkers [3, 4] including Edward Said [5] and Taha Hussein who criticized Le Bon's elitism and Centro-European points of view.

From the ideological perspective, the translated works of Zuāiter can be classified in two groups: (1) The first group includes those written by liberal thinkers on the Arab-Islamic civilization and related topics including

- Sedillot: Tārīkh al-'Arab al-'ām. (Histoire des Arabes);

- Le Bon: Hadārat al-'Arab. (La Civilisation des Arabes);

- Cara de Veaux (Vaux): Ibn Sina. (Avicenna);

(2) The second group is a diverse one, aimed to inform the Arab reader of the institutions, laws, etc. of western democracy, hoping that they may be utilized in the promised pan Arab state; to this group belong: Montesquieu Ruh ash-Sharā'i ('Esprit des Lois), Rosseau: 'Al-'aqad 'al-'Ijtimā'I (Du Contrat Social), Le Bon: As-Sunan an-Nafsiyyah Li-Tatawwur al-'Umam (Les Lois Psychologique de L'Evolution des Peuples).

Liberalism and Nationalism didn't always go in tandem in Zuāiter's translated works; and when they were contradictory in a work he abandoned translating it even after starting action: books of socialist orientation he never attempted, while many books by liberal writers he hesitated to translate or stopped translating later owing to his conviction of being 
contradictory to Arab- Islamic culture, of this group we may mention:

- Chateaubriand: ash-Shuhadā'. (Les Martyrs).

- Nietzsche: Huwa dha al-Insān (Human, all-toohuman).

- Rousseau: Al-'I'tirāfāt. (Les Confession).

- Rousseau: 'Ahlām Jā'il. (Reveries du Promeneur Solitaire).

In sum, state power caused Zuāiter to stop direct political activity against the Imperial project of the British Mandate in his homeland Palestine, and to consecrate his time and effort to translation for the sake of the Pan Arab renaissance movement. Moreover, his liberal ideology limited his translation to books of liberal thought, but in many cases his nationalism caused him not to choose certain liberal works or to stop translating them after commencement of work.

\section{Khayri Ḥammād}

Khayri Hammād was born in 1913 in Nablus, the city where Zuāiter was also born, and had his first years of education there. He began his higher studies in The Arab College in Jerusalem, then in the American University of Beirut from which he graduated with a first degree in library studies. Since his graduation, and even before, he became involved in politics and journalism, writing and editing of many newspapers and magazines in Iraq and Palestine, and following the Catastrophe Nakbah of 1948 in Jordan.

Though Hammād practiced translation earlier, in 1962 he became a full time translator, with English as the source language. His production of translation and writing was astonishing indeed, endowing the Arabic library with about 100 works; some raise the number to 120 , which lent him the description of a "phenomenon in translation".

The seemingly intriguing problem with Hammād is the difference in orientations between his translation and his writing; whereas he wrote books like "Clarifications and Viewpoints in Nationalism, Freedom and Socialism" defending socialist ideology and like "Observations in Europe" degrading capitalism and depicting an optimistic picture of the future of socialism in Europe and elsewhere, his translation of foreign works on socialism were relatively very few and even negligible.

For an explanation of this contradiction, financial temptation offered by liberal publishing houses may be proposed, but, it is the obstacles that count here: his involvement in certain governmental, or semi-governmental, institutions in the Arab countries was the main obstacle that hindered his translation of socialist thought. In fact, Hammād held many "Political" positions both in certain Arab governments, and also on the Arab interstate level; among these we may mention: Assistant Secretary General of
Palestinian writers on the Palestinian National Council. Therefore, this put enough pressure on him not to disseminate leftist views different from those claimed to be of "purely Arab" sources and origins; particularly Nasserite ones.

How Hammād managed to settle this abstruse situation, was the typical response adopted by many Palestinain writers and thinkers, like Iḥsan 'Abbās and Zuāiter himself, who almost gave up political activities and consecrated their efforts to academic work and translation. In the case of Hammād this shift was achieved mainly by translating contemporary and other historical works, like: "The Memories of Churchill", "The Memories of Antony Eden", "The Prince" of Machiavelli, etc. This he justified in introductions to some of his works, by statements similar to those of the following passage "Discourses of Machiavelli":

"We believe absolutely in freedom of thought, and we believe also in the necessity of informing the Arab reader fully of its horizons and domains, even when some of them contradict some of our beliefs. We also feel an insistent need for the necessity of introducing the theories and opinions of this man (the Author); theories that were destined to play a great role in directing international policies and events of the contemporary history", and also, in this passage from "The Memoirs of Churchill"

"This book will remain as one of the main references on which every following historian depends, in order to contrast his own narration of these events with the narrations of the others; thus the objective induction leading to absolute facts which every historian desires to attain, may be achieved."

\section{Salma Khadra Jayyusi}

Salma Khadra Jayyusi was born in East Jordan, of a Palestinian father and a Lebanese mother. She had her secondary education in Schmidt College for Girls in Jerusalem, graduated from the AUB in Arabic and English Literature, and later obtained a Ph.D. in Arabic Literature from London.

Salma Jayyusi started her literary activities as a poet, a translator and a critic; then she became a lecturer in several Arab and American universities. A major shift in her work took place in about 1980 when she initiated PROTA (Project of Translation from Arabic Literature) "after having realized how misrepresented and ignored abroad Arabic Literature and culture were [5]."

PROTA, a huge project in which a host of translators, both Palestinians/Arabs and native speakers of English participated together with its complementary project, East-West Nexus, resulted in the production of a large - and representative - number of translations including: many anthologies of different genres of 
modern Arabic Literature, for instance, modern Palestinian literature and modern Arabic fiction, works by single Palestinian or Arab authors; for example, The Secret Life of Saeed by Emile Habiby, books on ArabIslamic civilization such as The Legacy of Muslim Spain, and many other publications in English.

The national Palestinian and Arabic ideology of Salma Jayyusi hardly needs any expounding; in fact, the raison d'être for her project PROTA is defending Arab civilization and exposing it to the whole world as she affirmed in different occasions.

Concerning ideology, one can easily notice that texts with certain ideological trends, though not writers, namely leftist ones are generally absent from the selected material in some of her anthologies; this may explain or be explain by her disregard or denial of "ideological poetry", exemplified by her comment on the poetry of Mahmoud Darwish: [6].

“The universal quality of Darwish's poetry and prose stems primarily from his abhorrence of ideology - precondition, indeed for all great poetry. At the center of his work is not the "ideology" of the Palestinian struggle, but its tragic necessity, the inevitable need to stand defiantly against the radical disorder that has assailed the lives of Palestinians everywhere."

One may reasonably argue that "ideology" in Jayyusi's writing is equated to propaganda which is sharply different from the sense it has in this study; yet, the conclusions of her study do not affect that ideology (in the sense given to it in this study) politics or social factors, do have on literature, but she considers the essential matter "the human situation" that has to be tackled and not ideology and other external factors [6]:

"What is involved in this [Palestinian] literature, however, is not simply a political situation that has to be expounded to the whole world.... [but] perhaps the greatest achievement of contemporary Palestinian poetry is its subtle and esthetically sophisticated portrayal of a genuine existential situation. What we are rather concerned here is the question of justice and human happiness".

Salma Jayyusi was quite explicit in denouncing the misuse of power by Arab regimes, considering them the main obstacle against freedom of thought or writing; this is what she says in this respect:

"[In the Arab countries] the constitution is under the control of the secular authority, which often gets help from the religious authority in subjugating, convincing and misleading the people.... The political authority is not the sole one that stifles freedom; the religious societies participate in this act.... Yet, we must confess that the societal authority, despite its ferocity, remains less harsh than the political authority which is the bone-breaker and the origin of evil and aggression".

Though Jayyusi repeatedly proclaimed her discontent with the Arab regimes for not contributing to her grand project PROTA. Eventually, she was fortunate in not suffering from their prosecution; this may be partly explained by the fact that she practiced her activities abroad and that her selection of texts does not provoke disputes with Arab regimes.

From the above discussion and other relevant writings of Salma Jayyusi, one gets enough evidence of a second component of her own ideology; in addition to nationalism, namely, Humanism as expounded by Edward Said in some of his works. Thus, ideology of Jayyusi, understood in this manner, together with state power in the Arab world, may afford satisfactory answers to many questions related to her voluminous and valuable translations.

\section{CONCLUSIONS AND RECOMMENDATIONS}

1. Both English and French, as source Languages, were first used by the foremost Palestinian translators named in this study, but English monopolized the translational scene in the last decades becoming a major target language, too. This high status of English may be explained by power factors including the British Mandate in Palestine (1922-1947) and the wide political and economic influence of the USA in the region after World War II.

2. The translators, of this study, were generally creative writers, critics, poets, authors, or short story writers. This applies to many other Palestinian translators, both male and female, and can be explained by the common ideology they share i.e. nationalism which made them responsible for promoting Arab renaissance and defending the Palestinian cause.

3. Liberal ideology was very decisive by its partisan translators such as Zuaiter in limiting choice of texts to rightist ones and disregarding those of leftist tendencies. In the case of partisans of the left, ideology was much less effective than power of the state as evidenced by the missing of leftist texts in their translations, while being satisfied with texts of humanistic orientations instead.

4. Almost all the translated texts, involved in this study, belong to the domain of humanism, which is true also for Palestinian translation in general. However, they were diverse enough: law and thought by Zuaiter, literature, culture and criticism with Arabic as a source language by Jayyusi., history by Hammad.

5. Being of humanistic and diverse nature, Palestinian translation reflects, in fact, an ideological national impetus for driving the elites in particular, and the public in general to unify 
their efforts for the sake of the renaissance and gaining of power, by the Arab nation.

6. In reviewing the translated works by Palestinian translators in this study, it becomes manifest, and this is true of Palestinian translations in general, that their majority belong to liberal and national thought, which is easily explained by the balance of power in the related period. This leads us to recommend taking into consideration other ideologies like leftist, feminism, etc. in future translations.

7. The successful experience of PROTA (Project for Translation of Arabic Literature) and East-West Nexus, is an excellent example that the study recommends Arab universities of culture to utilize for informing the world of Arab literature and culture through different languages: French, Spanish, German, Chinese, Indian, etc.

8. Being exposed to the dangers of loss and neglect, the vast and invaluable wealth of Palestinian translation is urgently in need of salvage and study. This makes it imperative on Palestinian universities and other educational bodies, concerned with translation, to take on the responsibility of both rescuing these national treasures and conducting studies on them that are of more comprehensive scope both regarding translators and languages concerned.

\section{ACKNOWLEDGMENT}

It is my great pleasure to thank my university (Palestine Technical University-Kadoorie) for all the encouragment and support to achieve my research.

\section{REFERENCES}

1. Hamad, N. (2006). Abu-Dib's Translation of Orientalism.

2. Jaber, Y. (1997) Shaikh al-Mutarjemin al-Arab: Adel Zuaiter.

3. Ctford, J. C. (1965). A Linguistic Theory of Translation, London: OUP.

4. Said, E. (1994). Culture and Imperialism. New York: Knopf.

5. Jayyusi, S. (1992). Anthology of Modern Palestinian Literature. Columbia University Press. 